\title{
Neuronal COX-2 expression in human myenteric plexus in active inflammatory bowel disease
}

\author{
P J Roberts, K Morgan, R Miller, J O Hunter, S J Middleton
}

\begin{abstract}
Background-Inflammatory bowel disease (IBD) is associated with changes in colonic motility which may contribute to the pain and diarrhoea associated with exacerbations of this disease. These changes may be mediated by prostaglandins which are increased in this condition. Increased expression of the inducible isoform of cyclo-oxygenase (COX-2) has been found in active IBD although its cellular distribution remains uncertain.

Aims-To evaluate the cellular distribution of COX-2 in active IBD.

Patients and methods-Using reverse transcription-polymerase chain reaction, in situ hybridisation, and immunohistochemistry, COX-2 expression was evaluated in 12 colectomy specimens from patients with active ulcerative colitis (UC), and six specimens from patients with Crohn's colitis that had failed medical therapy. Histologically normal colon was obtained from 12 patients having resection for colorectal neoplasia and evaluated as above, acting as control specimens.
\end{abstract}

Results-All specimens expressed COX-2 mRNA, with some 6-8-fold increase in inflamed tissues on densitometric analysis (both UC and Crohn's) compared with controls. In situ hybridisation localised this mRNA to myenteric neural cells, surrounding smooth muscle cells, and inflammatory cells of the lamina propria in the IBD specimens, with some weaker labelling seen in the epithelium. No COX-2 labelling was seen in normal tissues. Immunohistochemistry confirmed these sites of COX-2 expression in all inflamed specimens, with absence of immunoreactivity in control tissues.

Conclusions-These findings provide the first evidence of COX-2 expression in neural cells of the myenteric plexus in active IBD which, via increased prostaglandin synthesis at this site, may contribute to the dysmotilty seen in this condition.

(Gut 2001;48:468-472)

Keywords: inducible cyclo-oxygenase; prostaglandins; myenteric plexus; inflammatory bowel disease

Correspondence to: Dr S J Middleton, Unit E7, Box 201A, Department of Gastroenterology,

Addenbrooke's NHS Trust, Cambridge CB2 2QQ, UK. stephen.middleton@msexc. addenbrookes.anglox.nhs.uk

Accepted for publication 31 October 2000

For many years it has been appreciated that there is altered colonic motility in active inflammation of the colon. ${ }^{1}$ Such alterations in colonic motor and myoelectric activities with resultant changes in transit may contribute to the pain and diarrhoea characteristic of an exacerbation of inflammatory bowel disease (IBD). ${ }^{2}$ The mechanisms of this dysmotility are uncertain but altered function of myenteric nerves and smooth muscle cells have been reported. ${ }^{2}$

Proinflammatory cytokines alter enteric nerve function which in the rat is thought to be mediated via prostaglandin production $\left(\mathrm{PGE}_{2}\right.$ primarily). ${ }^{3}$ Prostanoids are known to play significant physiological and pathophysiological roles in the gastrointestinal tract; regulating water and electrolyte transport, mucus secretion, blood flow, and motility. ${ }^{4}$ There is evidence of increased synthesis of $\mathrm{PGE}_{2}$ in the rat myenteric plexus after appropriate cytokine stimulation $^{3}$ and also in the rectal mucosa of patients with active IBD. ${ }^{5-7} \mathrm{PGE}_{2}$ has also been shown to modulate both non-adrenergic and non-cholinergic neurotransmission in the gastrointestinal tract of the rabbit. ${ }^{8}$

Further known effects of this prostanoid include stimulation of acetylcholine release from guinea pig myenteric plexus neurones with resultant changes in colonic contractility suggesting an effect via neural mechanisms. ${ }^{9}$ However, the effects of $\mathrm{PGE}_{2}$ on colonic motility in vivo are less certain. A decrease in sigmoid contractility occurs in humans during intravenous infusion of $\mathrm{PGE}_{2},{ }^{10}$ whereas stimulation of the distal colon occurs in the rabbit after a similar infusion, ${ }^{11}$ suggesting that the effects of prostaglandins on the control of colonic motility may be species specific.

Prostaglandin receptors have been reported on both enteric neural and smooth muscle cells of the guinea pig ileum, ${ }^{12}{ }^{13}$ but as yet there are no known reports of similar receptor expression in the human gastrointestinal tract.

There is increased expression of the inducible isoform of cyclo-oxygenase (COX-2) in both an animal model of colitis and in human $\mathrm{IBD}^{14-16}$ but with conflicting data on cellular localisation. In the animal model, COX-2 was primarily expressed in the subepithelium ${ }^{14}$ whereas epithelial expression was shown in human colitis ${ }^{15}$ with no study to date reporting COX-2 expression in neural cells of the colonic myenteric plexus. Therefore, we examined expression and localisation of this inducible isoform in full thickness surgical specimens, taken from patients with refractory IBD.

Abbreviations used in this paper: IBD, inflammatory bowel disease; $\mathrm{PGE}_{2}$, prostaglandin $\mathrm{E}_{2}$; COX, cyclo-oxygenase; RT-PCR, reverse transcription-polymerase chain reaction; G3PDH, glyceraldehyde-3-phosphate dehydrogenase; SSC, standard saline citrate; UC, ulcerative colitis; PGP, protein $\mathrm{G}$ peptide; iNOS, inducible nitric oxide synthase. 
Table 1 Characteristics of patient groups

\begin{tabular}{|c|c|c|c|}
\hline & Histologically normal specimens & UC specimens & Crohn's specimens \\
\hline \multicolumn{4}{|l|}{ Age (y) } \\
\hline Mean & 55 & 40 & 43 \\
\hline Range & $40-78$ & $33-64$ & $28-57$ \\
\hline $\operatorname{Sex}(M / F)$ & $7 / 5$ & $6 / 6$ & $4 / 2$ \\
\hline \multirow[t]{3}{*}{ Medication } & Nil & Azathioprine $(2.5 \mathrm{mg} / \mathrm{kg}, \mathrm{n}=7)$ & Azathioprine $(2.5 \mathrm{mg} / \mathrm{kg}, \mathrm{n}=6)$ \\
\hline & & 5 -ASA $(2.4 \mathrm{~g} /$ day, $\mathrm{n}=10)$ & 5 -ASA $(2.4 \mathrm{~g} /$ day, $\mathrm{n}=4)$ \\
\hline & & Methylprednisolone $(\mathrm{n}=12)$ (mean $500 \mathrm{mg} /$ day) & Methylprednisolone $(\mathrm{n}=6)$ (mean $500 \mathrm{mg} /$ day) \\
\hline Site of disease & $\begin{array}{l}\text { Left sided neoplasm }(n=7) \\
\text { Right sided neoplasm }(n=5)\end{array}$ & Pancolitis $(n=12)$ & Pancolitis $(n=6)$ \\
\hline Histological diagnosis & $\begin{array}{l}\text { Tubulovillous adenoma }(n=2) \text {, } \\
\text { adenocarcinoma }(n=10)\end{array}$ & Active colitis & Active colitis with granulomas \\
\hline
\end{tabular}

5-ASA, aminosalicylic acid.

\section{Materials and methods}

PATIENTS AND SPECIMENS

Histologically normal tissue was obtained from colectomy specimens from patients with colorectal neoplasia from a site distant from the lesion $(n=12)$ and surgical specimens were obtained from a similar site in patients undergoing surgery for refractory ulcerative $(n=12)$ and Crohn's $(n=6)$ colitis. Tissue was immediately frozen and stored at $-70^{\circ} \mathrm{C}$ and post fixed as required. Characteristics of the patient groups are shown in table 1.

REVERSE TRANSCRIPTION-POLYMERASE CHAIN REACTION (RT-PCR)

Tissue samples were collected as discussed, and immediately frozen in liquid nitrogen. Total RNA was purified from $200 \mathrm{mg}$ of tissue according to the method of Chomczynski and Sacchi. ${ }^{17}$ This entailed homogenisation in guanidine thiocyanate solution, acid phenol/ chloroform extraction, and isopropanol precipitation. RNA pellets were washed in $70 \%$ ethanol, dissolved in sterile water, and stored at $-70^{\circ} \mathrm{C}$. Aliquots of each RNA sample $(5 \mu \mathrm{g})$ were reverse transcribed to produce single stranded cDNA with a kit (Invitrogen, USA) using random primers and avian myeloblastosis virus reverse transcriptase. Samples of cDNA (50 ng) were then analysed by PCR amplification using pairs of oligonucleotide primers specific for COX-2. Primer sequences were: 5' gTT CCA CCC gCA gTA CAg 3' sense, and 5' ggA gCg ggA AgA ACT TgC 3 'antisense primer, amplifying a $483 \mathrm{bp}$ cDNA fragment.

Each PCR reaction contained $1 \times \mathrm{NH}_{4} \mathrm{CL}$ PCR buffer, $1.875 \mathrm{mM} \mathrm{MgCl}_{2}, 0.1 \mu \mathrm{M}$ of each primer, $0.5 \mathrm{mM}$ dNTPs, $1 \mu \mathrm{Ci}{ }^{32} \mathrm{P}$-dCTP, and 2.5 units of BioTaq DNA polymerase (Bioline, UK). Following five minutes of denaturation at $93^{\circ} \mathrm{C}$, hot start reactions were initiated (annealing at $60^{\circ} \mathrm{C}$ for 30 seconds, extension at $72^{\circ} \mathrm{C}$ for 30 seconds, and denaturation at $93^{\circ} \mathrm{C}$ for 30 seconds) and run for up to 35 cycles. Semiquantitative PCR data were generated by kinetic analysis and comparison with levels of glyceraldehyde-3-phosphate dehydrogenase $(\mathrm{G} 3 \mathrm{PDH}) \mathrm{mRNA}$. Reaction products were analysed by $6 \%$ polyacrylamide gel electrophoresis and film autoradiography using radiolabelled DNA size markers. Amplification products separated in this way were excised and eluted from the gel into $0.5 \mathrm{M}$ ammonium acetate and ethanol precipitated. The identity of the product was confirmed by direct cycle sequencing using a kit (Circumvent, New England Biolabs, USA).

IN SITU HYBRIDISATION

Fresh tissue samples were fixed by immersion in $1 \%$ paraformaldehyde in phosphate buffered saline. Samples were then frozen in cryostat embedding compound for preparation of $10 \mu \mathrm{m}$ sections on 3-aminopropyltriethoxysilane coated slides. Sense and antisense ${ }^{32} \mathrm{P}$ labelled single stranded DNA probes were generated by PCR. Riboprobes were generated using T7 RNA polymerase after making templates by PCR with an appropriate T7 promoter tagged primer. Probes were purified by phenol/chloroform extraction and ethanol precipitation and were washed six times with $70 \%$ ethanol to remove unincorporated nucleotides. The probes were dissolved in water, denatured at $90^{\circ} \mathrm{C}$ for one minute, cooled on ice, and serially diluted in hybridisation buffer $(50 \%$ formamide, $6 \times$ standard saline citrate (SSC), $5 \times$ Denhardt's solution (containing bovine serum albumin, ficoll, and polyvinyl pyrrolidone), $100 \mu \mathrm{g} / \mathrm{ml}$ sheared and denatured herring sperm DNA, and $100 \mu \mathrm{g}$ total RNA from baker's yeast.) Sections were hybridised under siliconised coverslips at $42^{\circ} \mathrm{C}$ overnight in humidified chambers. Coverslips were removed in $5 \times$ SSC at room temperature and racks of slides were washed at $42^{\circ} \mathrm{C}$ in $2 \times \mathrm{SSC}$, $1 \times$ SSC, and $0.5 \times$ SSC for 20 minutes in each solution. Washed slides were allowed to dry before performing film autoradiography (with Amersham Hyperfilm B-max, 24-72 hour

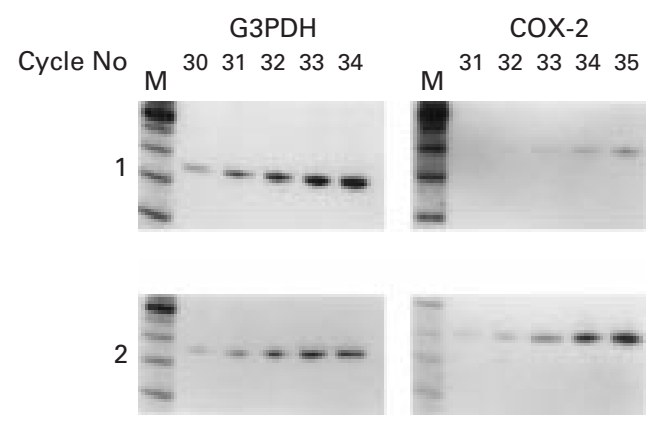

Figure 1 Example of kinetic polymerase chain reaction $(P C R)$ analysis of $C O X-2$ expression in normal (1) and ulcerative colitis (UC) (2) tissue. Densitometric analysis revealed greater expression (up to eightfold) of $C O X-2$ product in 12/12 UC and 5/6 Crohn's specimens compared with normal tissue when standardised with respect to glyceraldehyde-3-phosphate dehydrogenase (G3PDH) levels. PCR cycle lengths: G3PDH 30-34, COX-2 31-35. $M, D N A$ size markers from Gibco BRL, UK. 

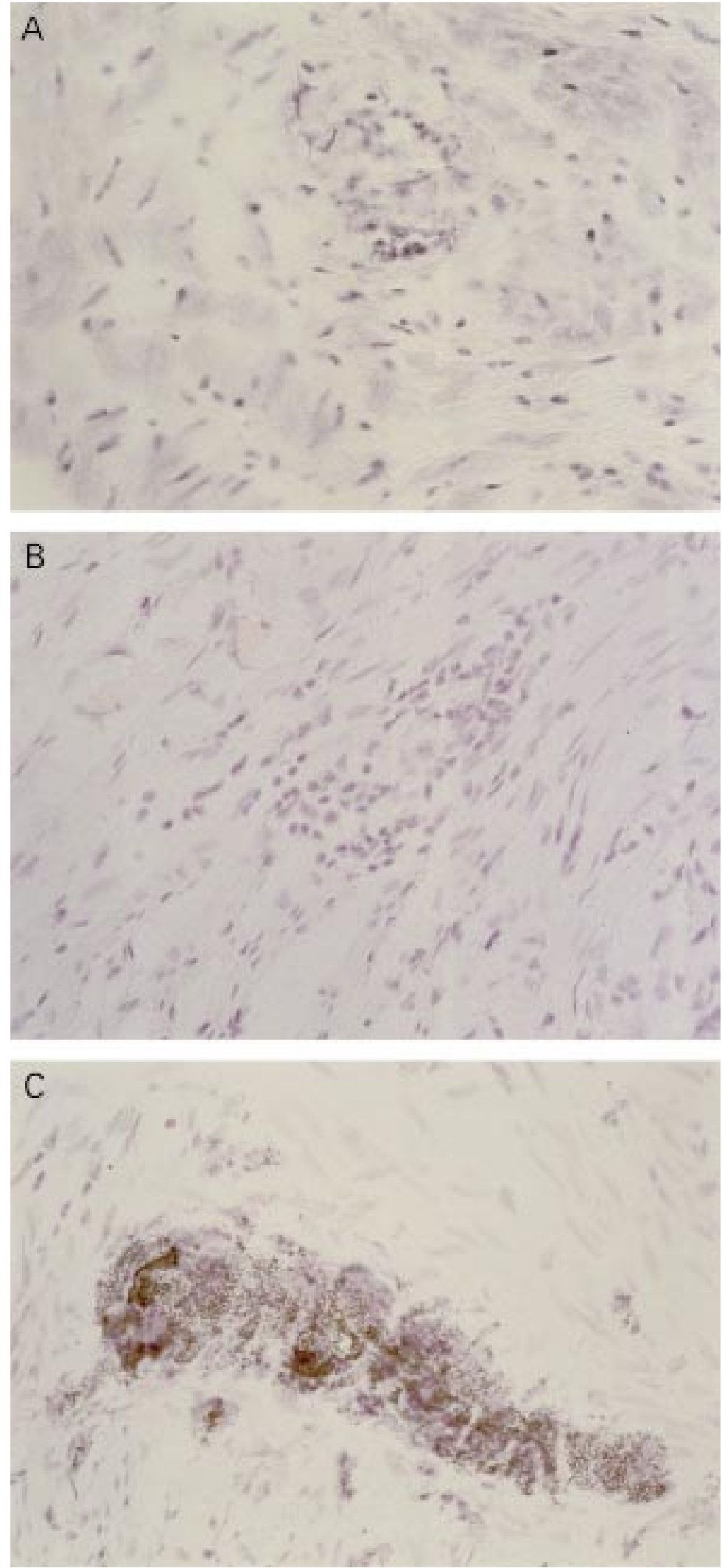

Figure 2 Example of COX-2 in situ hybridisation of surgical resection specimens. (A) Non-inflamed control tissue and antisense probe, with no labelling seen. (B) Diseased tissue (ulcerative colitis (UC) specimen) and sense probe - no labelling. (C) Diseased tissue (UC) and antisense probe with intense labelling of neural cells of the myenteric plexus. Similar results were obtained irrespective of the mode of inflammation - that is, in both UC and Crohn's specimens COX-2 mRNA was localised to the same cell types. exposure) followed by emulsion autoradiography (2-5 days with Ilford K5 liquid emulsion). Silver grains were developed using Kodak D-19 developer and fixed in dilute Amfix (Champion, UK). Sections were counterstained, coverslipped, viewed, and photographed.

\section{IMMUNOHISTOCHEMISTRY}

COX-2 protein expression was examined in tissue using a standard ABC Vectastain technique. Tissue sections were post fixed in $1 \%$ paraformaldehyde. Briefly, endogenous peroxidase activity was blocked in tissue sections (10 $\mu \mathrm{m}$ sections on 3-aminopropyltriethoxysilane coated slides) using endogenous peroxidase suppressor "Immunopure" (Pierce Laboratories) for 22 minutes followed by application of normal goat serum (1:20) to block non-specific staining for 30 minutes. The primary antibody, a rabbit polyclonal raised against COX-2, was obtained from Cayman Chemical (Ann Arbor, Michigan, USA). This was applied to serial sections at a concentration 1:1000 and incubated for one hour at room temperature. Following this the second antibody was applied, a goat antirabbit biotinylated antibody (applied at $5 \mu \mathrm{g} / \mathrm{ml}$, obtained from Vecta Laboratories, California, USA). This was further probed with $\mathrm{AB}$ Vectastain and developed with diaminobenzadine tetrahydrochloride dihydrate for 3-5 minutes, with resultant brown staining indicating sites of COX-2 immunolocalisation. Normal rabbit serum (concentration up to $2 \mu \mathrm{g} / \mathrm{ml}$ ) was applied on serial sections as a negative control. Sections were counterstained with haematoxylin $(1: 20)$. Localisation of COX-2 was compared with that of the neural marker protein G peptide (PGP9.5) and COX-1 (the constitutive isoform of cyclooxygenase) using appropriate antibodies against these proteins.

\section{Results}

Using RT-PCR all specimens, normal and diseased, were shown to express COX-2 mRNA. Kinetic PCR analysis revealed increased COX-2 expression (up to eightfold on densitometry) in 12/12 ulcerative colitis (UC) and 5/6 Crohn's specimens compared with normals when standardised to the level of G3PDH expression (fig 1). In situ hybridisation localised COX-2 mRNA to the myenteric plexus (neural cells and smooth muscle) in all UC specimens (12/12) evaluated and in 5/6 of the Crohn's specimens, with labelling also seen in inflammatory cells of the lamina propria in all of these inflamed tissues. No COX-2 labelling was seen in normal controls (fig 2). Immunohistochemistry localised COX-2 protein to myenteric neural and smooth muscle cells in all UC and in 5/6 Crohn's specimens. PGP was coexpressed at these sites confirming neural cell expression of COX-2 in the inflamed tissues. There was also COX-2 immunoreactivity in the epithelium of 7/12 UC and 4/6 Crohn's specimens with absence of COX-2 immunoreactivity at any site in normal tissue (fig 3). 

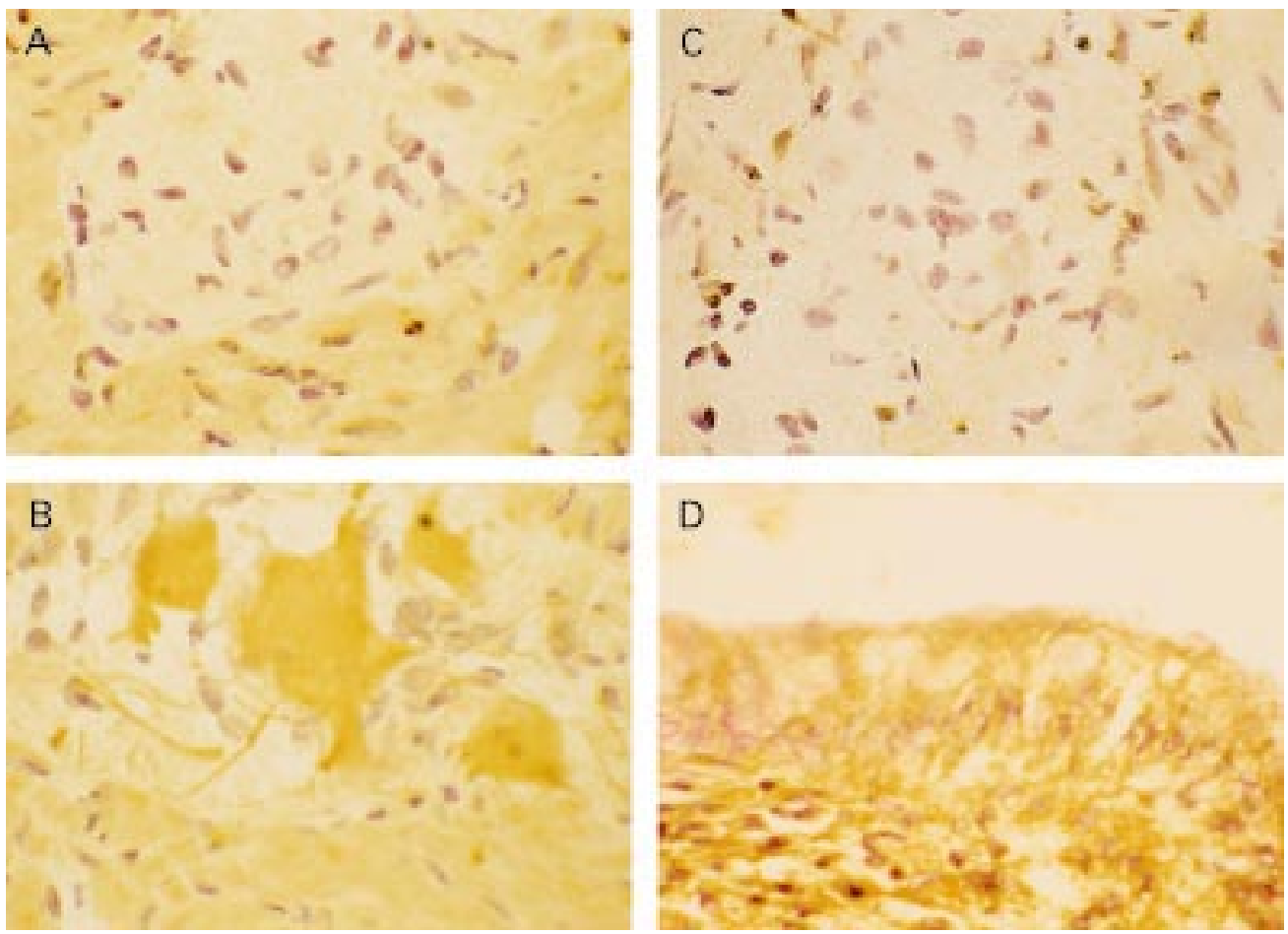

Figure 3 Example of immunolocalisation of COX-2. (A) Non-immune (control) serum-diseased tissue (ulcerative colitis (UC)), with no staining seen. (B) COX-2 labelling (brown stain) of neural cells of the myenteric plexus in diseased tissue (UC). (C) Absence of COX-2 labelling in myenteric plexus of normal tissue. (D) Labelling of epithelial cells with COX-2 in diseased tissue (UC).

\section{Discussion}

Our data confirm previous studies suggesting increased COX-2 expression in active IBD, ${ }^{14-16}$ with labelling of the colonic epithelium and inflammatory cells of the lamina propria. However, we have also shown expression of this enzyme in neural cells of the myenteric plexus in active colonic inflammation, an as yet unpublished finding. ${ }^{15}$ Using antibodies to both neural cells (PGP9.5) and macrophages (anti-CD68, data not shown) we were able to show specific neural cell expression of COX-2 in the human myenteric plexus and not in activated macrophages at this site, as suggested in a previous report. ${ }^{3}$ The subepithelial expression of COX-2 is consistent with the findings in TNBS induced colitis in rats $^{14}$ which with transmural inflammation is histologically more similar to Crohn's colitis than UC. Therefore, we were not surprised to find COX-2 production in the myenteric plexus in Crohn's colitis, although no neural cell labelling was seen in the TNBS animal model. The finding of COX-2 expression at this site in the UC specimens was less expected as UC is felt to be, in the main, a mucosal disease.

In certain cell systems a recognised stimulus for COX-2 expression is mechanical stress which would have occurred during the manipulation and resection of the colonic specimens. ${ }^{18}$ However, the absence of any COX-2 expression in both smooth muscle cells and neural tissue in the normal specimens (using localisation techniques) would suggest that such physical effects play no role in the expression of COX-2 in our specimens, as all tissue examined was obtained in a similar manner (that is, resection at laparotomy).
In studies of patients with chronic ulcerative colitis there is reduced colonic contractility, ${ }^{19}$ reduction in basal colonic intraluminal pressure, ${ }^{20}$ and a marked reduction in postprandial motility. ${ }^{21}$ In both human and animal models of colitis there appears to be a relationship between altered colonic motility and abnormal local release of various inflammatory mediators of which prostaglandins such as $\mathrm{PGE}_{2}$ are of considerable importance. ${ }^{22} 23$

Toxic megacolon is a severe and life threatening consequence of the dysmotility of acute IBD. Mucosal nitric oxide (NO•) is increased in active $\mathrm{IBD}^{24-26}$ and a recent report evaluating expression of the inducible isoform of nitric oxide synthase (iNOS) in UC suggested increased production of this inflammatory enzyme in the muscle layers of the colon and implicated the resultant nitric oxide as the mediator of the reduced contractility and consequent toxic megacolon. ${ }^{27}$ None of our specimens was taken from patients with toxic dilatation of the colon which may explain the absence of iNOS expression in the muscle layers of these tissues in our study (data not shown). The role of COX-2 at this site in toxic megacolon is still poorly understood. However, with COX-2 expression in both smooth muscle and neural cells of the myenteric plexus in active colitis, it is plausible that the resultant prostanoids from COX-2 enzyme activity at this site might be of importance in the pathogenesis of toxic megacolon.

It has been suggested that selective inhibition of COX-2 is beneficial in states of inflammation. ${ }^{28}$ This may not be the case in acute colitis however as such inhibition in an animal model of colitis increased mortality, ${ }^{14}$ with no similar 
human study to date. Therefore, although there is increased production of COX-2 in active IBD it is not known whether using selective COX-2 inhibitors would be beneficial, although this remains a possibility, specifically with regards to toxic colonic dilatation.

In summary, we have shown a new finding of COX-2 expression in neural cells of the myenteric plexus during active IBD, and suggest that such enzyme expression at this site may link colonic inflammation, prostaglandins, and colonic dysmotilty.

1 Kern FJ, Almy TP, Abbot FK, et al .Motility of the distal colon in nonspecific ulcerative colitis. Gastroenterology 1951;19:492-503.

2 Cironi L, Mchugh K, Collins SM, et al. On the specificity of altered muscle function in experimental colitis in rats. Gasaltered muscle function in experim

3 Rühl A, Berezin I, Collins SM, et al. Involvement of eicosanoids and macrophage like cells in cytokine mediated changes in

4 Robert A. Prostaglandins and the gastrointestinal tract. In: Johnson CR, ed. Physiology of the gastrointestinal tract. New York: Raven, 1991:1407-34

5 Gould SR. Assay of prostaglandins like substances in faeces and their measurement in ulcerative colitis. Prostaglandin 1976;11:489-97.

6 Hawkey CJ, Karmelli F, Rachmilewitz D, et al. Imbalance of prostacyclin and thromboxane synthesis in Crohns disease. Gut 1983;24:881-5.

7 Sharon PA, Ligumsky M, Rachmilewitz D, et al. Role of prostaglandins in ulcerative colitis: enhanced production during active disease and inhibition by sulfasalazine. Gastroenterology 1978;75:638-40.

8 Baccari MC, Calamai F, Staderini G, et al. Prostaglandin E2 modulates neurally induced nonadrenergic noncholinergic modulates neurally induced nonadrenergic noncholinergic
gastric relaxation in the rabbit in vivo. Gastroenterology gastric relaxation

9 Bennett A, Eley KG, Stockley HL, et al. Modulation by prostaglandins of contractions in guinea-pig ileum. Prostaglandins 1975;9:377-84

10 Hunt RH, Dilawari JB, Misiewicz JJ, et al. The effects of intravenous prostaglandins $\mathrm{F} 2 \alpha$ and $\mathrm{E} 2$ on the motility of the sigmoid colon. Gut 1975;16:47-9

11 Pairet M, Bouyssou T, Ruckebush Y, et al. Colonic formation of soft faeces in rabbits: a role for endogenous prostaglandins. Am F Physiol Gastrointest Liver Physiol 1986; 250:G302-4.
12 Lawrence RA, Jone RL, Wilson $\mathrm{NH}$, et al. Characterization of receptors involved in the direct and indirect actions of prostaglandins E and I on the guinea-pig ileum. Br f Pharmacol 1992:105:271-8.

13 Botella A, Delvaux M, Fioramonti J, et al. Stimulatory (EP1 and EP3) and inhibitory (EP2) prostaglandin E2 receptors in isolated ileal smooth muscle cells. Eur F Pharmacol 1993; 237:131-7.

14 Reuter BK, Asfaha S, Buret A, et al. Exacerbation of inflammation associated colonic injury in rat through inhibition of cyclooxygenase 2. 7 Clin Invest 1996;98:2076-85.

15 Singer II, Kawka DW, Schloemann S, et al. Cyclooxygenase 2 is induced in colonic epithelial cells in inflammatory 2 is induced in colonic epithelial cells in inflam

16 Hendel J, Nielson OH. Expression of cyclooxygenase mRNA in active inflammatory bowel disease. Am $\mathcal{F}$ Gastroenterol 1997;92:1170-3.

17 Chomczynski P, Sacchi N. Single step method of RNA isolation by acid guanidinium thiocyanate-phenol-chloroform extraction. Anal Biochem 1987;162:156-9.

18 Akai Y, Homma T, Burus KD, et al. Mechanical stretch/ relaxation of cultured cells induce protooncogenes and cyclooxygenase. Am f Physiol Cell Physiol 1994;267:C48290.

19 Snape WJ, Williams R, Hyman PE, et al. Defect in colonic smooth muscle contraction in patients with ulcerative colitis. Am f Physiol 1991;261:G987-91.

20 Snape WJ, Matarazzo SA, Cohen S, et al. Abnormal gastrocolonic response in patients with ulcerative colitis. Gut 1980;21:392-6

21 Reddy SN, Bazzocchi G, Akashi k, et al. Colonic motility and transit in health and ulcerative colitis. Gastroenterology 1991;101:1289-97.

22 Caprilli R, Orion L. Pathogenesis of gastrointestinal distension in severe ulcerative colitis: a hypothesis. Gastroenterol sion in severe ulce

23 Snape WJ, Kao HW. Role of inflammatory mediators in colonic smooth muscle function in ulcerative colitis. Dig Dis Sci 1988;33:655-705.

24 Middleton SJ, Shorthouse M, Hunter JO. Increased nitric oxide synthesis in ulcerative colitis. Lancet 1993;341:465-6.

25 Boughton-Smith NK, Evans SM, Hawkey CJ, et al. Nitric oxide synthase activity in ulcerative colitis and Crohn's disease. Lancet 1993;342:336-40.

26 Singer II, Kawka DW, Scott S, et al. Expression of inducible nitric oxide synthase and nitrotyrosine in colonic epithelium in inflammatory bowel disease. Gastroenterology 1996; 111:871-85

27 Mourelle M, Casellas F, Guiarner F, et al. Induction of nitric oxide synthase in colonic smooth muscle from patients with toxic megacolon. Gastroenterology 1995;109:1497-502.

28 Masferrer JL, Zweifel BS, Manning PT, et al. Selective inhibition of inducible cyclooxygenase 2 in vivo is antiinflammatory and non-ulcerogenic. Pharmacology 1994;91: $3228-32$ 